\title{
10. SEA-FLOOR MAGNETIC PATTERNS AND BASEMENT STRUCTURE IN THE SOUTHEASTERN PACIFIC
}

\author{
Ellen M. Herron and Brian E. Tucholke, Lamont-Doherty Geological Observatory \\ of Columbia University, Palisades, New York
}
"Had I been present at the creation, I would have given some useful hints for the better ordering of the universe." -Alphonso the Learned

\section{INTRODUCTION}

The basic pattern of sea-floor spreading in the South Pacific has been described by numerous authors including Pitman et al. (1968); Herron and Hayes (1969); Herron (1971, 1972); and most recently by Molnar et al. (1975). Two major spreading centers have been active during the Cenozoic: the Pacific-Antarctic Ridge between New Zealand and Antarctica and the Chile Ridge between the Pacific-Antarctic Ridge and the Chile Trench north of $46^{\circ} \mathrm{S}$ (Figure 1). Both of these ridges bound the Antarctic crustal plate, and their relative motion has been described as a northward migration away from Antarctica (Herron, 1971, 1972). If this relatively simple three plate system-Antarctic, Pacific and Nazca (and its predecessor, the Farallon)-was the only system operative in the southeast Pacific during the Mesozoic and Cenozoic, Mesozoic magnetic anomalies such as those found in the northwestern Pacific and north Atlantic (Larson and Chase, 1972; Vogt et al., 1971) should be present in the extreme southeast Pacific. As outlined in Figure 2, however, there is little evidence of Mesozoic oceanic crust in the southeastern Pacific, and the magnetic anomalies identified in this region suggest a very complex history for West Antarctica and the Antarctic Peninsula.

One objective of drilling on Leg 35 was to determine the age of Layer 2 at several places in the Bellingshausen Basin in the southeasternmost Pacific in order to better understand the complex tectonic evolution of the area. Sediment overlying basalt was dated as (?) Oligocene to lower Miocene at Site 322 and Upper Cretaceous (Maestrichtian) at Site 323. Drilling at Sites 324 and 325 did not reach basalt, but extrapolation of observed sedimentation rates at the latter site suggests an age of latest Oligocene for basement. In this report we outline the tectonic fabric of the crust in the southeast Pacific and consider the Leg 35 drilling results in light of possible models for the tectonic evolution of the basin.

\section{METHODS}

The tectonic fabric of crustal Layer 2 in the southeast Pacific is inferred largely from seismic profiler and 12 $\mathrm{kHz}$ echo-sounding data and from aeromagnetic and surface-ship magnetic data.

The Bellingshausen Basin was studied in detail using seismic profiler and sonobuoy data acquired during U.S.N.S. Eltanin cruises 17, 19, 21, 23, 42, and 43 .
Records from the first four of these cruises are of marginal quality. Additional data were acquired on $\mathrm{R} / \mathrm{V}$ Conrad cruise 15 and R/V Vema cruise 18. With the exception of Vema 18, which used explosives, all records were obtained with an airgun sound source (2025 in. $^{3}$ ) and were usually filtered between 30 and $120 \mathrm{~Hz}$. Records were obtained on Leg 35 of Glomar Challenger with two 40 in. $^{3}$ airguns, or a 20 in. $^{3}$ and a 40 in. ${ }^{3}$ airgun operated simultaneously, and these data were usually filtered between 80 and $640 \mathrm{~Hz}$. The higher frequency recording in the Challenger records, together with the strong reflectivity and thickness of sediments, usually prevented resolution of acoustic basement.

Some of the profiler data from this area has been reported previously (M. Ewing et al., 1968; M. Ewing et al., 1969; J. Ewing et al., 1971; Houtz et al., 1973; and Houtz, 1974), but these papers were devoted largely to the sedimentary record. However, these authors have reported the presence of rough basement with little sediment cover in the Drake Passage and in the southeastern Pacific between about $57^{\circ}$ and $60^{\circ} \mathrm{S}$.

We use the term basement to define the shallowest occurrence of basalt or material with sound velocities characteristic of basalt $(4.5$ to $5.5 \mathrm{~km} / \mathrm{sec})$. Usually this corresponds to the "deepest observed reflector" or "acoustic basement" in the seismic profiler records. However, in certain locations weak coherent echoes persist below acoustic basement, or sonobuoy solutions indicate that material with velocities of 4.5 to $5.5 \mathrm{~km} / \mathrm{sec}$ lies deeper than acoustic basement, and in these instances true basement is inferred to occur below acoustic basement.

The magnetic data reported here have been obtained on the above cruises as well as on Vema cruise 16 and on Project Magnet flights 720, 721, 722, 723, and 724 (U.S. Naval Oceanographic Office Geomagnetic Survey, 1970).

\section{TECTONIC FABRIC OF THE SOUTHEAST PACIFIC}

Five sets of magnetic lineations with three distinct trends are identified within the area depicted in Figure 2: (1) north-northeast-trending anomalies of Cretaceous to Holocene age associated with the Pacific-Antarctic Ridge; (2) north-northwest-trending anomalies of Eocene to Holocene age associated with the Chile Ridge (and with its predecessor, the Antarctic-Farallon or Fossil Ridge); (3) northeast-trending anomalies of 


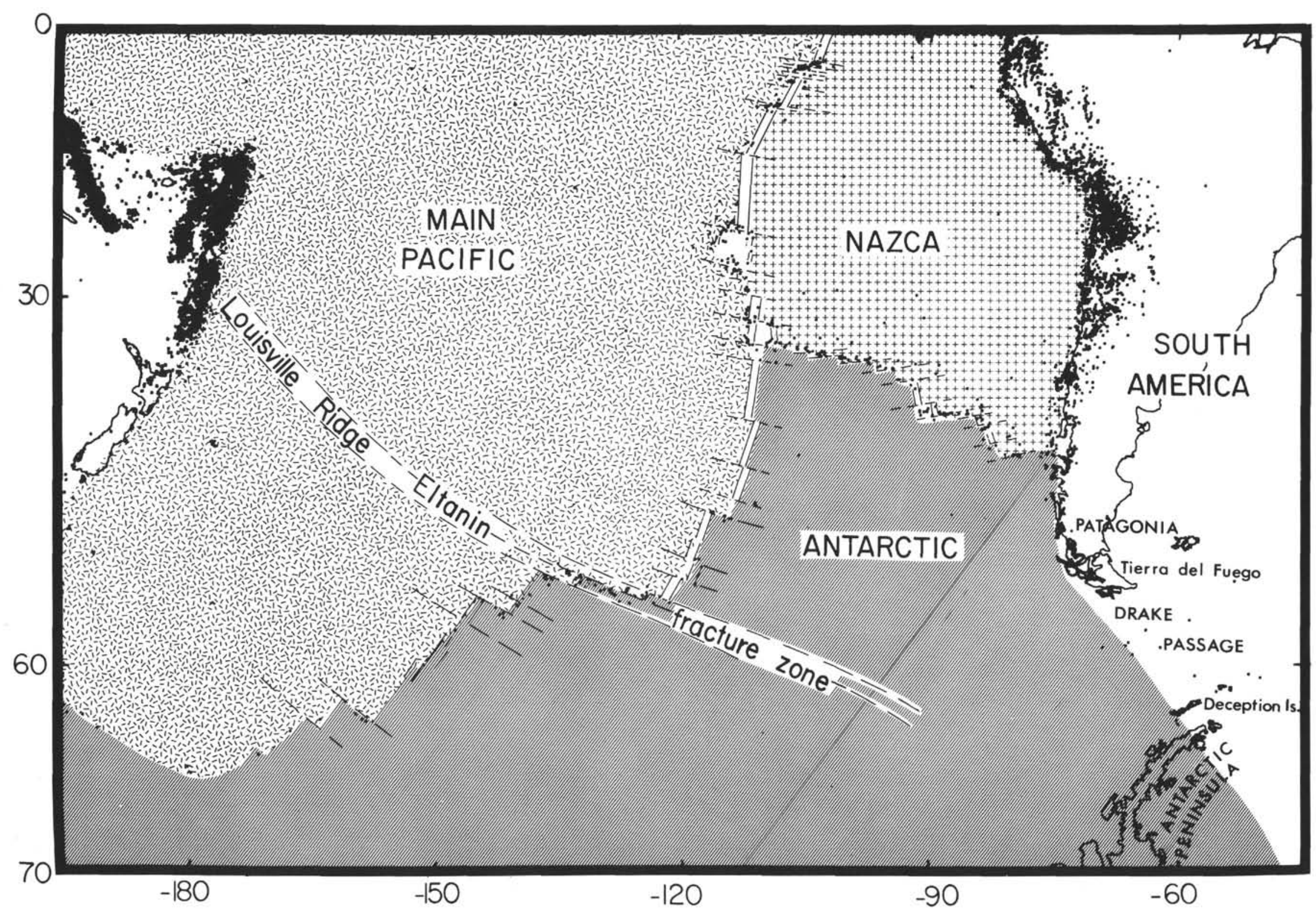

Figure 1. Present configuration of crustal plates in the South Pacific, as outlined by earthquake epicenters (after Herron, 1972). 


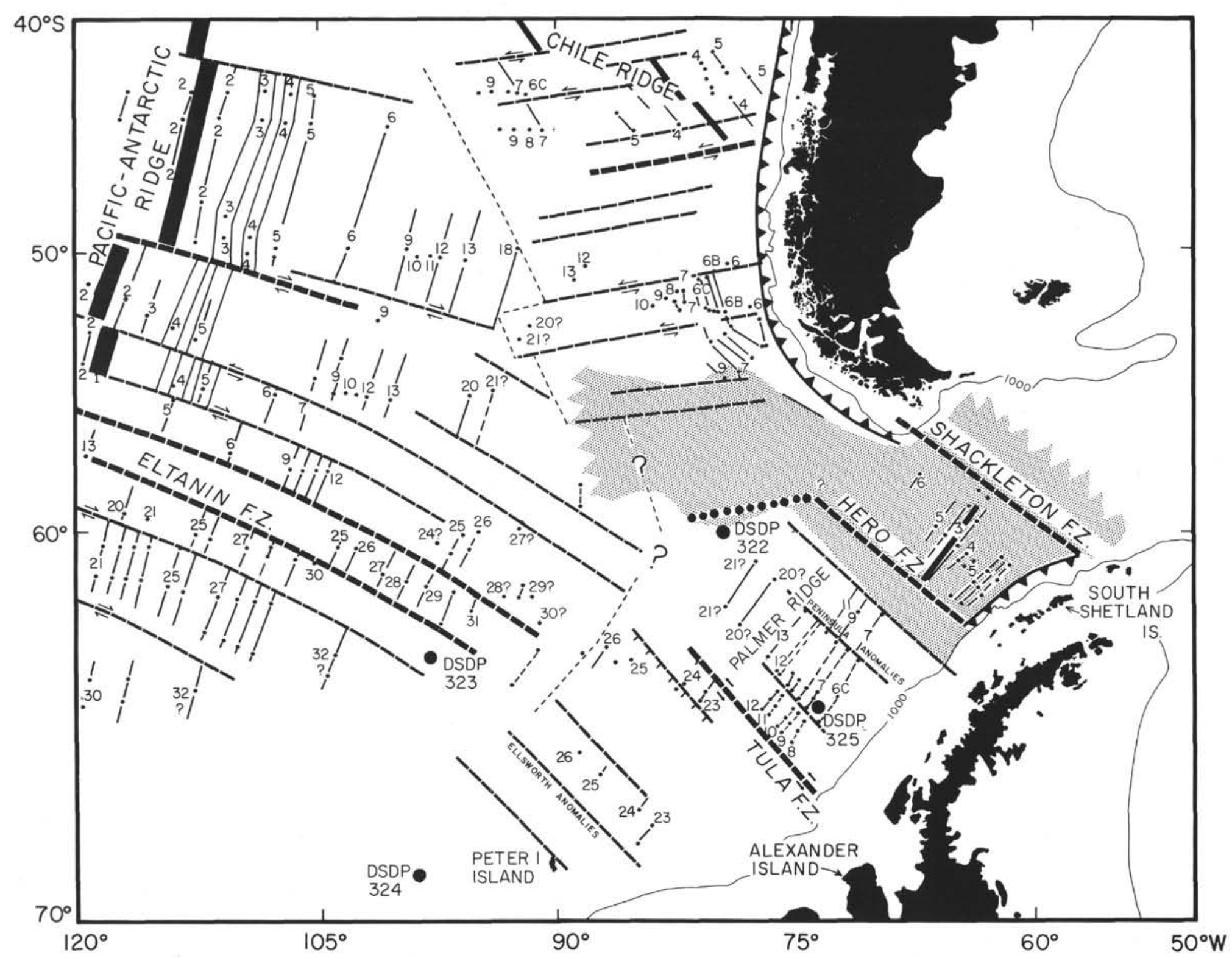

Figure 2. Summary of magnetic and structural lineaments in the Southeast Pacific Basin. The axes of active spreading centers are outlined by the heavy solid line, and magnetic lineations (nomenclature of Pitman et al., 1968) are shown by the lighter solid lines, or by short dashed lines where control is poor. Heavy broken lines locate major fracture zones, and the lighter dashed lines define the boundary between crust generated at the Pacific Antarctic Ridge and at the Antarctic-Farallon and Aluk ridges. Shaded area denotes region of very rough topography. Trenches are shown by the dragon's teeth. 
Miocene to Pliocene age in the Drake Passage; (4) a second northeast-trending set of Eocene to Oligocene age seaward of the Antarctic Peninsula; and (5) a third northeast-trending set of Late Cretaceous to Paleocene age seaward of Alexander Island and Ellsworth Land in West Antarctica. The first three sets of magnetic lineations have been discussed extensively by various authors (Pitman et al., 1968; Herron, 1971, 1972; Herron and Hayes, 1969; Molnar et al., 1975; Barker, $1971)$ and are reviewed only briefly here; emphasis in this paper is placed on the two sets of anomalies identified adjacent to the Antarctic Peninsula and Ellsworth Land.

The largest and best-known tectonic lineament in the South Pacific is the Eltanin Fracture Zone (Figure 1). It consists of a pair of major faults which offset magnetic anomalies and the Pacific-Antarctic Ridge crest nearly $1000 \mathrm{~km}$ in a right lateral sense (Pitman et al., 1968; Herron, 1971; Molnar et al., 1975). Relief along this fracture zone varies with longitude; the fault is much better developed in both bathymetric and profiler records west of the crest of the Pacific-Antarctic Ridge than to the east. Hayes and Ewing (1971) suggested that the western Eltanin Fracture Zone continued to the Tonga-Kermadec Trench as the Louisville Ridge. There is, however, no known counterpart of the Louisville Ridge in the southeast Pacific basin.

A pair of sediment-filled troughs extending to about $93^{\circ} \mathrm{W}$ identifies the eastern end of the Eltanin Fracture Zone (Figures 3 and 4 ). Although the northern fracture is better developed, both the southern and northern fractures commonly exhibit a high, steep, north wall, and the basement morphology between the two faults is rugged. Possible extension of the Eltanin Fracture Zone east of about $93^{\circ} \mathrm{W}$ is much more difficult to ascertain; although local sediment-filled deeps lie along the eastward-extrapolated trends of the fractures, they are not well defined, and the fill in some areas is so strongly reflective that it is suggestive of basalt flows (Profile E, Figure 4). In addition, the adjacent basement topography is greatly subdued compared to that west of $93^{\circ} \mathrm{W}$.

Northeast of the Eltanin Fracture Zone, two paralleltrending fracture zones are also suggested by geophysical data (Figure 3). Basement relief decreases eastward along the trend of these features, but the decrease is not as pronounced as that along the Eltanin Fracture Zone.

East of these fracture zones, Layer 2 becomes extremely rugged and lies at depths between about 4500 and 5200 meters (Figures 2 and 5). Although bathymetric data are not adequate for precise definition of structural lineations in this area, the available bathymetry (Mammerickx et al., 1974a, 1974b; bathymetry in cover pocket) and the sediment distribution (Tucholke and Houtz, this volume) suggest that east-southeast trends persist eastward to at least $80^{\circ} \mathrm{W}$. A large trough northwest of Site 322 extends to 5806 meters and lies near the eastern end of an east-southeasttrending series of major basement depressions contoured by Mammerickx et al. (1974a, 1974b).

Northeast of this area, study of magneic anomalies over the Chile Ridge led Herron and Hayes (1969) and
Herron $(1971,1972)$ to suggest that the Chile Ridge is only a small remnant of a once much larger ridge system that predates the East Pacific Ridge and once dominated the central Pacific. To date, few data have been available for studying the possible southward extension of the primordial Chile Ridge beyond the present triple junction at $46^{\circ} \mathrm{S}$. As shown in Figure 2, magnetic data south of the triple junction and seaward of the sediment-filled and virtually aseismic Chile Trench support the suggestion that the southern extension of the Chile Ridge was an active spreading center as recently as $20 \mathrm{~m}$.y. ago (anomaly 6). Accretion at the ridge crest ceased when the spreading center was consumed by the Chile Trench. A detailed study of these Patagonian lineations is the basis of a separate paper (Herron, in preparation); however, the lineations are important in deriving models for possible plate configurations during the Cenozoic. The southern limit of these anomalies is of obvious interest but is not well-defined. Intuitively, we suggest that the sharp southern terminus of the area of very rough topography may form this boundary (dot series in Figure 2).

The northeast-trending anomalies along the West Antarctic margin are subdivided into three sets. The first set is identified in the Drake Passage between the South Shetland Islands and Tierra del Fuego. Barker (1971) identified the anomalies as of Miocene to Pliocene age. In contrast to other sets of anomalies along the western margin of West Antarctica, the Drake Passage anomalies are the only ones which show a symmetrical anomaly pattern. The magnetic anomalies occur within an area of rugged abyssal hills and are bounded by welldefined transform plate boundaries: the Shackleton Fracture Zone on the northeast, and the Hero Fracture $Z^{2} e^{1}$ on the southwest. The southeast-trending Hero Fracture Zone is defined by a marked increase in basement depth toward the southwest (Figure 3). It intersects the continental slope of the Antarctic Peninsula near $62^{\circ} 30^{\prime} \mathrm{S}, 64^{\circ} \mathrm{W}$ at the southwestern end of the South Shetland Trench. A parallel fracture zone farther southwest is indicated by a similar offset in crustal depth. Seismic activity associated with the Drake Passage spreading center and the bounding fracture zones (Barazangi and Dorman, 1969) and continuing volcanic activity at Deception Island on the Antarctic Peninsula (Baker et al., 1969) suggest that this ridge may still be active, although the youngest identifiable magnetic anomaly was formed during the Pliocene, 4 to $5 \mathrm{~m}$.y. ago. The oldest magnetic anomalies indicate that the ridge has been active for at least 20 m.y.

Seaward of the central Antarctic Peninsula, magnetic anomalies of Miocene to Eocene age can be identified, and they are here termed the peninsula anomalies (Figures 2 and 6). Like the anomalies in the Drake Passage, the peninsula anomalies trend northeast, but the anomaly age increases away from the Antarctic margin, indicating that the spreading center where these lineations formed has been subducted beneath the Antarctic Peninsula. However, thick continental rise

\footnotetext{
'Named for R/V Hero, a veteran Antarctic research ship and escort vessel for the Glomar Challenger during Leg 35.
} 


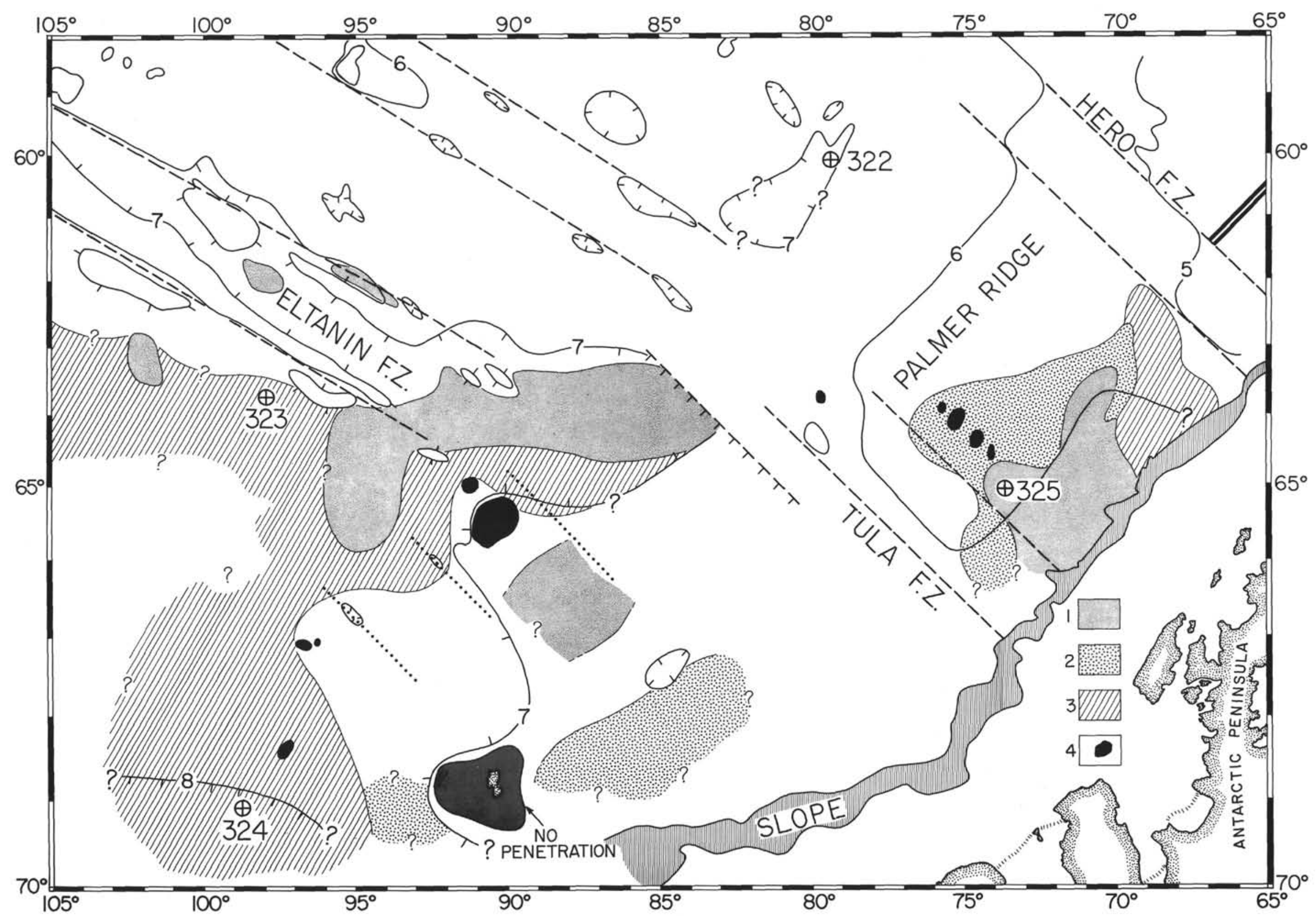

Figure 3. Map of depth to basement (in seconds reflection time below sea level) and character of acoustic basement in Bellingshausen Basin: 1-very smooth acoustic basement, 2-moderately smooth, 3-moderately irregular, 4-major peaks interrupting continental rise. Unpatterned deep-sea areas have irregular acoustic basement (or undefined, near slope). Probable and possible faults are shown by dashed and dotted lines. Heavy dual line is axis of spreading center in Drake Passage. 

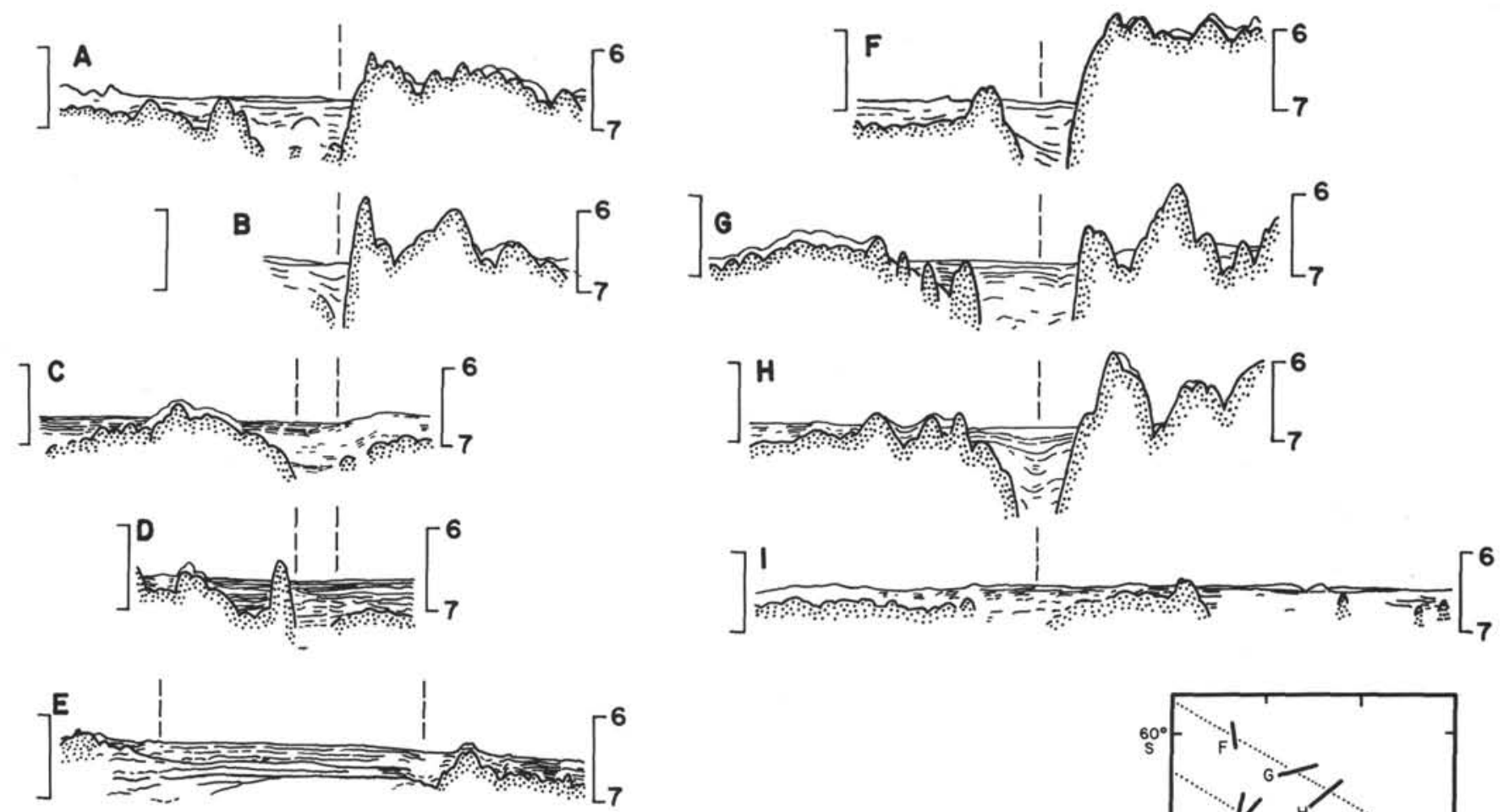

SOUTHERN

NORTHERN

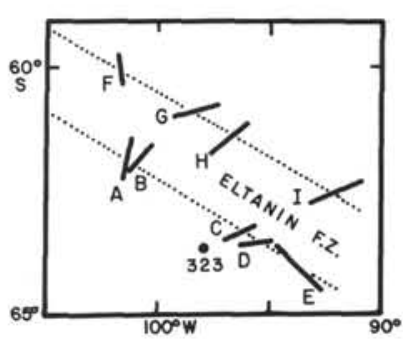

Figure 4. Tracings of seismic profiler records across eastern end of Eltanin Fracture Zone. Depth (right) in seconds reflection time. Inset shows location.

sediments now lie along the margin both here and farther to the southwest, and there is no evidence in either free-air gravity or profiler data for a trench along the Antarctic Peninsula (Figures 7 and 8).

Variations in basement morphology and an anomaly offset define a minor fracture zone near Site 325 (see Schroeder, this volume). A major fault, herein called the Tula Fracture Zone, ${ }^{2}$ appears southwest of Site 325 and marks the southwestern boundary of the peninsula anomalies. Like the Hero Fracture Zone, it is defined by a pronounced increase in basement depth to the southwest, and it also has a southeasterly trend. Although the Tula Fracture Zone is covered by more than a kilometer of sediment, it is still expressed in the sea-floor morphology (see bathymetry in cover pocket).

Basement shallower than $6 \mathrm{sec}$ (reflection time) is confined northeast of the Tula Fracture Zone where it forms a broad structural ridge seaward of Site 325 and trends parallel to the magnetic anomalies (Figures 3 and $5)$. We refer to this feature as the Palmer Ridge.

All magnetic data across the peninsula anomalies have been projected along an azimuth of $120^{\circ}$ (Figure 6). Synthetic magnetic anomalies generated for this latitude and azimuth are also shown, and they illustrate the close correlation between observed and computed

\footnotetext{
${ }^{2}$ Named for the brig Tula, in which Captain John Biscoe circumnavigated Antarctica in 1832 .
}

magnetics. In particular, three short wavelength anomalies identified as number $6 \mathrm{C}$ are well displayed in the data and can be used as a critical test of the anomaly identification. Anomalies $6 \mathrm{C}$ through 8 are identified with a high degree of confidence, and the late Oligocene crustal age inferred from Site 325 drilling data supports the identification; identifications of anomalies 9 through 12 are more tenuous, and identifications of anomalies 13 through 21 are very speculative. Half-spreading rates measured on anomalies 6C to 11 average slightly less than $2 \mathrm{~cm} / \mathrm{yr}$. Anomalies older than number 11 appear to have been generated at a slightly slower spreading rate, although the small confidence in the correlation makes such measurements of little value. The skewness of the theoretical anomalies agrees with the northeasterly trend proposed for the lineations and supports the southeasterly trend derived from seismic data for fracture zones near these lineations. As noted previously, the trend of these lineations is nearly parallel to that of the younger lineations in the Drake Passage, as well as parallel to the lineations observed farther southwest along West Antarctica. However, this trend and the trend of the fracture zones differ significantly from the trends of the anomalies and fracture zones associated with the older parts of the Pacific-Antarctic Ridge system (Figure 2).

The third set of lineations along the Antarctic margin is the Ellsworth anomalies southwest of the Tula Frac- 

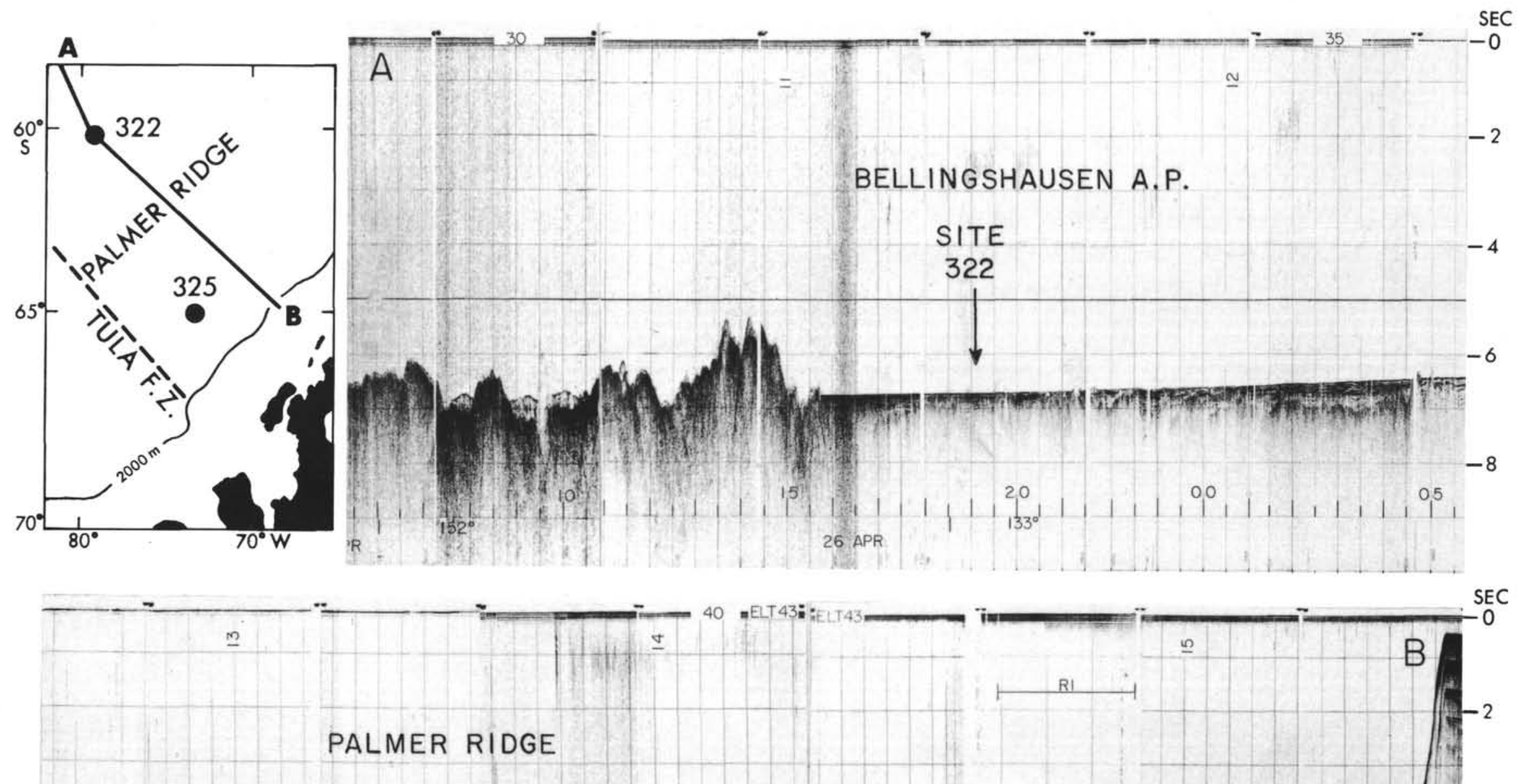

PALMER RIDGE

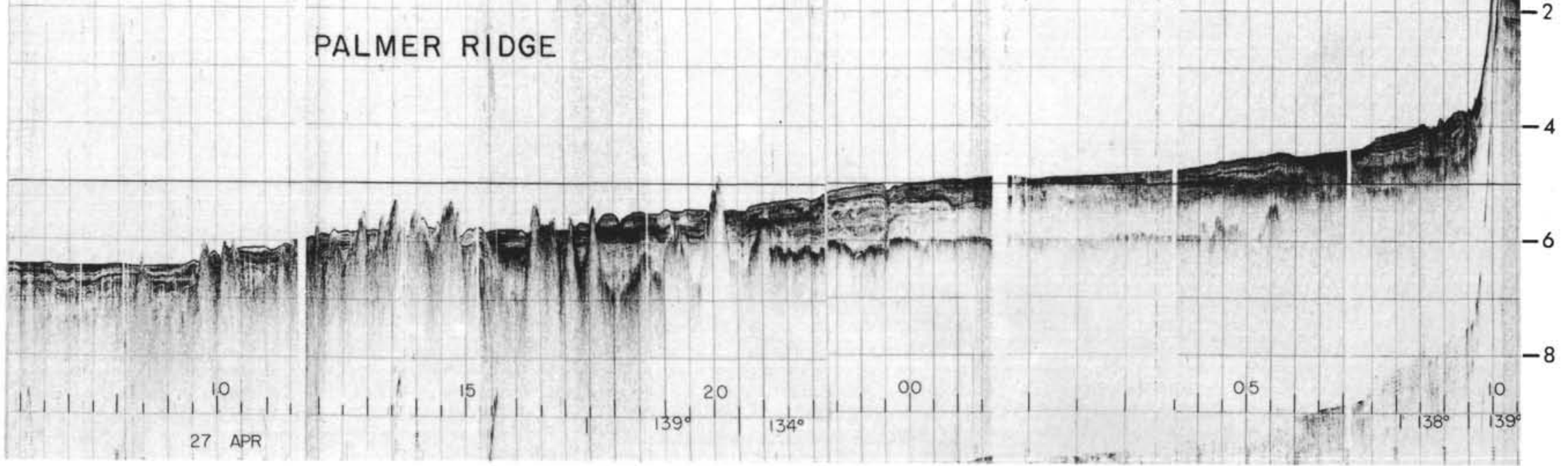




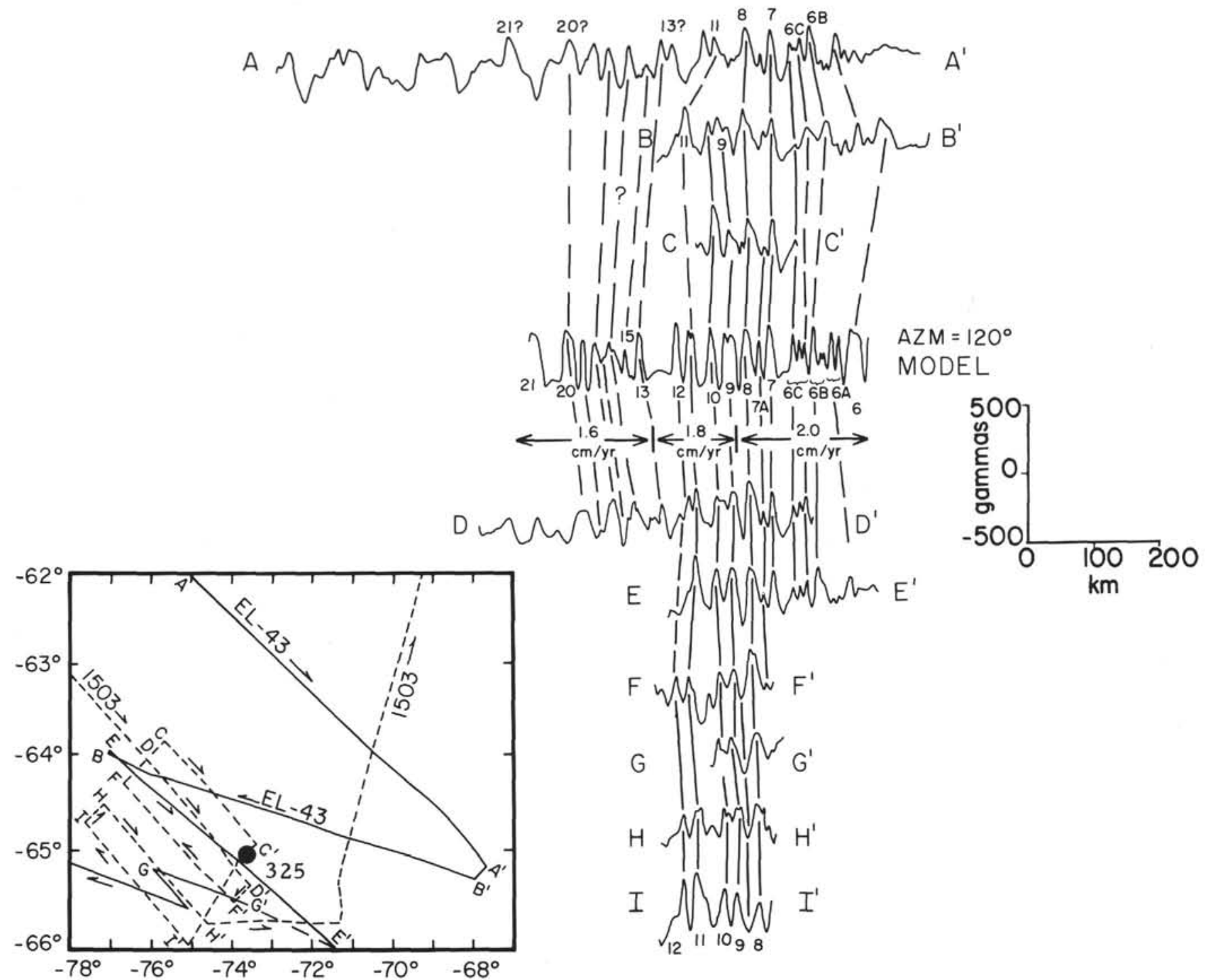

Figure 6. Projected magnetic data in the area near DSDP Site 325, together with model which best fits the data.

ture Zone (Figures 2 and 9). These anomalies are cut by several probable faults, the best defined of which lies just west of the seaward end of the Tula fracture Zone. The fault forms a west-facing scarp in the basement with 400-700 meters of relief. Our limited magnetic data across this fault indicate no horizontal offset. To the southwest, three additional faults are suggested where seismic profiler data show major clefts in basement (Figure 3). Their trend is inferred to parallel the fracture zones to the northeast.

The Ellsworth anomalies are the most interesting lineations observed along the margin, but are also the least understood. Their wavelengths are double or triple the wavelengths of the peninsula anomalies, and many small-amplitude anomalies are superimposed on the long-wavelength anomalies. However, they have the same trend as anomalies northeast of the Tula Fracture Zone and also increase in age away from Antarctica.

As shown in Figure 9, we have correlated the Ellsworth anomalies with a sequence of early Tertiary magnetic reversals generated at a half-spreading rate of about $6 \mathrm{~cm} / y r$. Figure 9 also incorporates two models to illustrate the dependence of anomaly shape on azimuth of the lineations, and a profile from the Indian Ocean (Cande, personal communication) that illustrates the extremely good agreement between the Indian Ocean anomalies and the Ellsworth anomalies. Even the smallscale anomalies between anomalies 24 and 27 can be correlated between the two sets of data. Because of this excellent correlation between the Pacific and Indian ocean data and the computed model anomalies, we are confident of the validity of our anomaly identification. The configuration of crustal plates operative at the time of formation of these anomalies is much more speculative.

The two older sets of anomalies along the West Antarctic margin southwest of the Hero Fracture Zone define crust generated by Cenozoic spreading centers which have been subducted beneath West Antarctica. We have termed this spreading center the Aluk Ridge and its southern plate the Aluk plate, in an inverted analog of Grow and Atwater's (1970) "Kula" plate in 

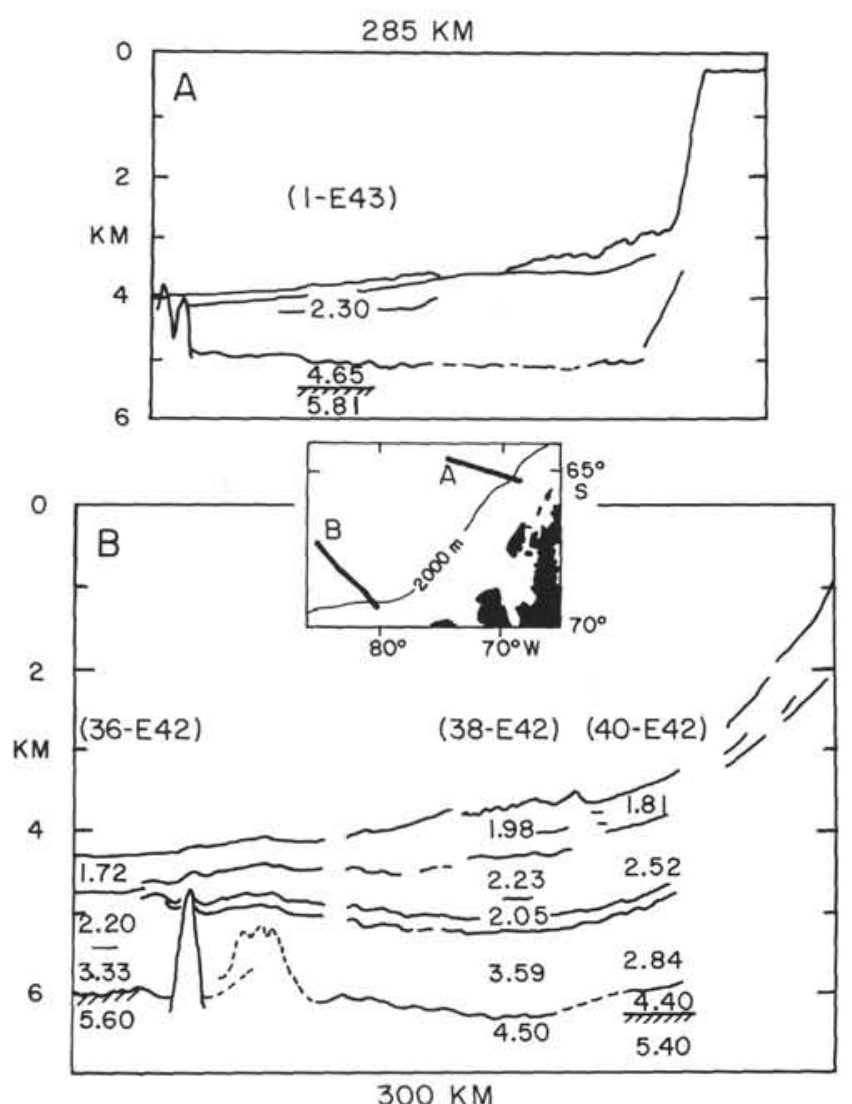

Figure 7. Tracings of continental margin profiles northeast (upper) and southwest (lower) of Tula Fracture Zone showing true sediment thickness from sonobuoy-determined velocities $(\mathrm{km} / \mathrm{sec})$. Inset shows location. Modified from Houtz (1974).

the northeast Pacific. The segment of the Aluk Ridge that generated the Ellsworth anomalies appears to have been consumed beneath West Antarctica in the late Paleocene, whereas the segment that generated the peninsula anomalies was not subducted until the early Miocene. Although it is tempting to consider the Ellsworth, peninsula, and Drake Passage anomaly sets as evidence for the progressive northeastward subduction of the Aluk Ridge analogous to the situation that may exist off the coast of southern Chile, the absence of any identifiable time overlap in the three anomaly sets may also suggest that each of the ridge segments represents a discrete and distinct configuration of small plates in the circum-Antarctic region. Thus, the contemporary spreading center in the Drake Passage may or may not be a modern remnant of the Aluk Ridge, with a fragment of the Aluk Plate remaining between the ridge axis and the South Shetland Islands. The terms Aluk Ridge and Aluk plate may more properly refer to a composite sequence of ephemeral ridges and crustal plates generated in response to changes in the patterns of motions of the major plates in the circum-Antarctic region.

\section{AGE-DEPTH RELATIONSHIPS}

Figure 3 includes generalized contours of depth to basement in seconds reflection time below sea level. A comparison with the corresponding section of Figure 2 shows that there is a general correlation between the age of the sea floor and the depth of basement. Basement predating anomaly 26 in the western part of the Bellinghausen Basin lies deeper than $7 \mathrm{sec}$. Structural control of basement depth is apparent to the east, where the younger crust shoals and is more easily studied in our profiler data.

In Figure 10, basement depth (corrected for sediment overburden) is plotted against crustal age determined from magnetic anomalies. Basement depth was determined from seismic reflection profiles, and each depth is an average over about $30 \mathrm{~km}$ of track. The correlation between basement depth and the generalized age-depth curve of Sclater et al. (1971) broadly supports the validity of our anomaly identifications. Much of the scatter observed in the data results from (1) irregular basement morphology, and (2) imprecision in determining the thickness of sediment overburden, which is derived from a best-fit velocity-depth curve for Bellingshausen Basin sonobuoy solutions (Tucholke and Houtz, this volume, fig. 9). Thus the scatter is greatest for the Ellsworth anomalies where sediment thickness varies from about 0.8 to $2.5 \mathrm{~km}$, and it is somewhat less for the peninsula anomalies with less than about $1.2 \mathrm{~km}$ of sediment cover.

The Palmer Ridge is of interest in the context of agedepth relationships because its northeast strike and position seaward of a presumed former trench suggest that it may have originated as a crustal upwarp seaward of the subduction zone. The occurrence and formation of such outer ridges along the North Pacific margin are discussed by Watts and Talwani (1974). In the case of the Palmer Ridge, however, we have the added complexity that a Neogene spreading ridge, rather than old, cool crust, has been subducted. There is presently little indication in either the gravity (Figure 8 ) or in the agedepth relationships over the ridge (anomalies 7-13) for its origin as a crustal upwarp, although the increasing sediment overburden toward Antarctica appears to have sustained the observed basement attitude.

Basement depths at Sites 322 and 323, corrected for sediment overburden, are plotted in Figure 10. The depth of Site 322 crust suggests an age of about 60 m.y. (anomaly 23) which agrees with our magnetic interpretation, but is in dramatic contrast to the basalt age indicated by drilling (10-15 m.y. [paleontology]). Possible reasons for this discrepancy are considered below in the discussion of basin evolution. The depth of Site 323, on the other hand, agrees closely with the paleontologic age of basement (Maestrichtian) and the age predicted by the observed magnetic anomaly.

\section{POSSIBLE MODELS FOR CRUSTAL EVOLUTION}

Despite the excellence of magnetic anomaly data in the South Pacific, the large number of undefined variables (such as the limits of crust generated by the various spreading centers; the geologic structure of West Antarctica; and the history of deformation along the Alpine Fault of New Zealand) render attempts to determine plate boundaries extremely difficult. One can play almost endlessly with various permutations and combinations of available data and still not be able to define 

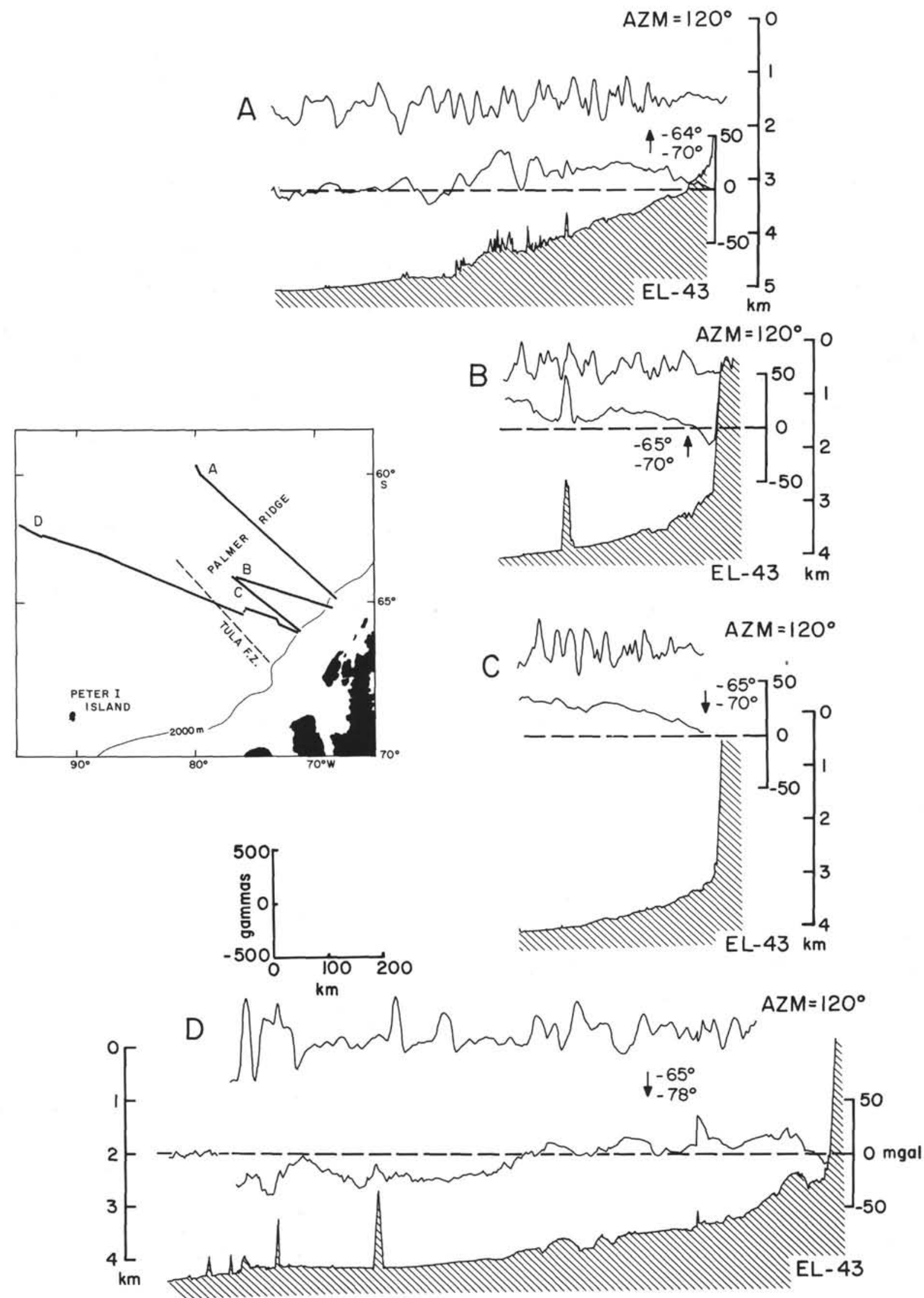

Figure 8. Projected profiles showing magnetic anomalies, free-air gravity anomaly, and topography along the Bellingshausen continental margin. Inset shows true location. 


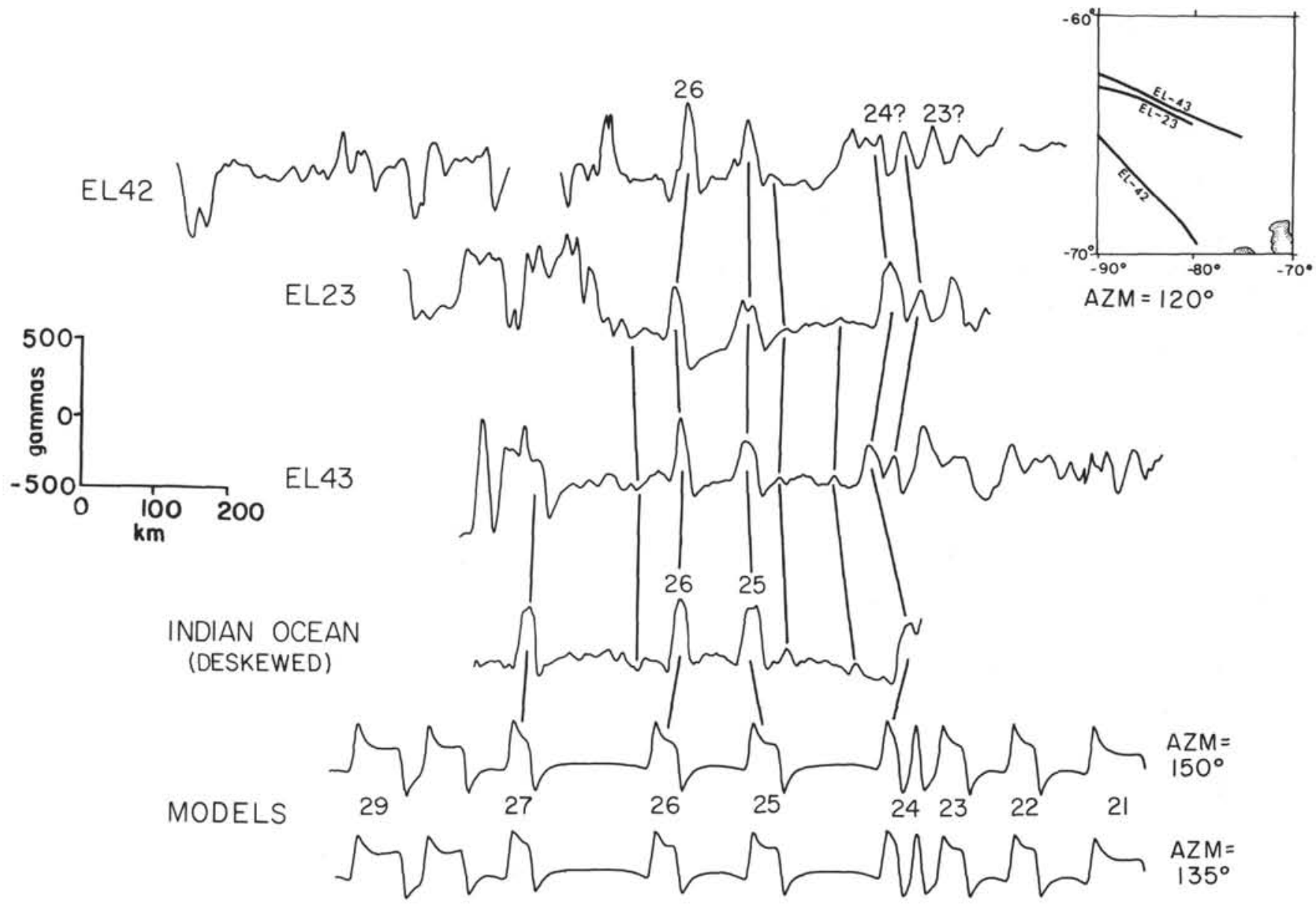

Figure 9. Projected magnetics data for Ellsworth anomalies, together with computed models and a projected profile from the Indian Ocean (courtesy of S. Cande). The two models are shown to illustrate the close dependence of anomaly shape on azimuth. The Indian Ocean profile was obtained close to the equator where the shape of magnetic anomalies varies sharply with slight changes in latitude and orientation. For ease in comparison with other magnetic anomalies, obtained at higher latitudes where the shape of the anomalies is more "stable," this profile has been deskewed (phase shifted to match the amplitude and phase of the observed anomalies).

a model which is distinctly more plausible than several others. Figures 11 and 12 illustrate several sketches based roughly on reconstructions by McKenzie and Sclater (1971) and Molnar et al. (1975) together with the data presented in this paper. These cartoons are presented only to illustrate one significant result of this study; namely, the necessity for dividing Antarctica into at least two spearate crustal plates between about 80 and 20 m.y. ago. This is not a new idea. Molnar et al. (1975) and Hayes and Ringis (1973) are among those who have invoked or postulated such a division; the presence of the Cenozoic alkaline volcanics of Marie Byrd Land and the active volcanism of Mount Erebus near McMurdo Sound support the concept of a plate boundary between East and West Antarctica. Stump (1973) has developed this idea further, suggesting that West Antarctica consists of four or five distinct crustal platelets.

Figure 11 shows only two possible reconstructions for 71-75 m.y. The Ellsworth anomalies, generated in the latest Cretaceous and Paleocene at an axis with a very high spreading rate, are the most troublesome to understand. We have not identified any continuation of these anomalies northeast of the Tula Fracture Zone or west of Peter I Island (Figure 2). If the anomalies do continue west of Peter I Island, they would imply westward continuation of the fast-spreading ridge to a triple junction between West Antarctica and New Zealand (Figure 11a). Alternatively, the absence of the anomalies west of Peter I Island would suggest that even at the beginning of the Cenozoic, the Antarctic Peninsula was not part of the same crustal plate as Marie Byrd Land (Figure 11b). The reconstruction by Molnar et al. (1975) (Figure 11a), with their arbitrary slicing of East and West Antarctica, results in an unacceptable overlap of South America by the Antarctic Peninsula. Dalziel and Elliot (1971) have argued that the Antarctic Peninsula was colinear with southern South America until the mid-Tertiary. The reconstruction does, however, satisfy assumptions of Molnar et al. (1975) about the history of the Alpine Fault Zone in New Zealand and the closure of the Tasman Sea.

A second set of models for the configuration of crustal plates between 20 and $50 \mathrm{~m} . \mathrm{y}$. ago is presented in Figure 12. These sketches are constrained by slightly more geophysical data than are available for the early Cenozoic, but it must be emphasized again that the solution presented in Figure 12 is not unique. We have suggested that a spreading center may have been active 


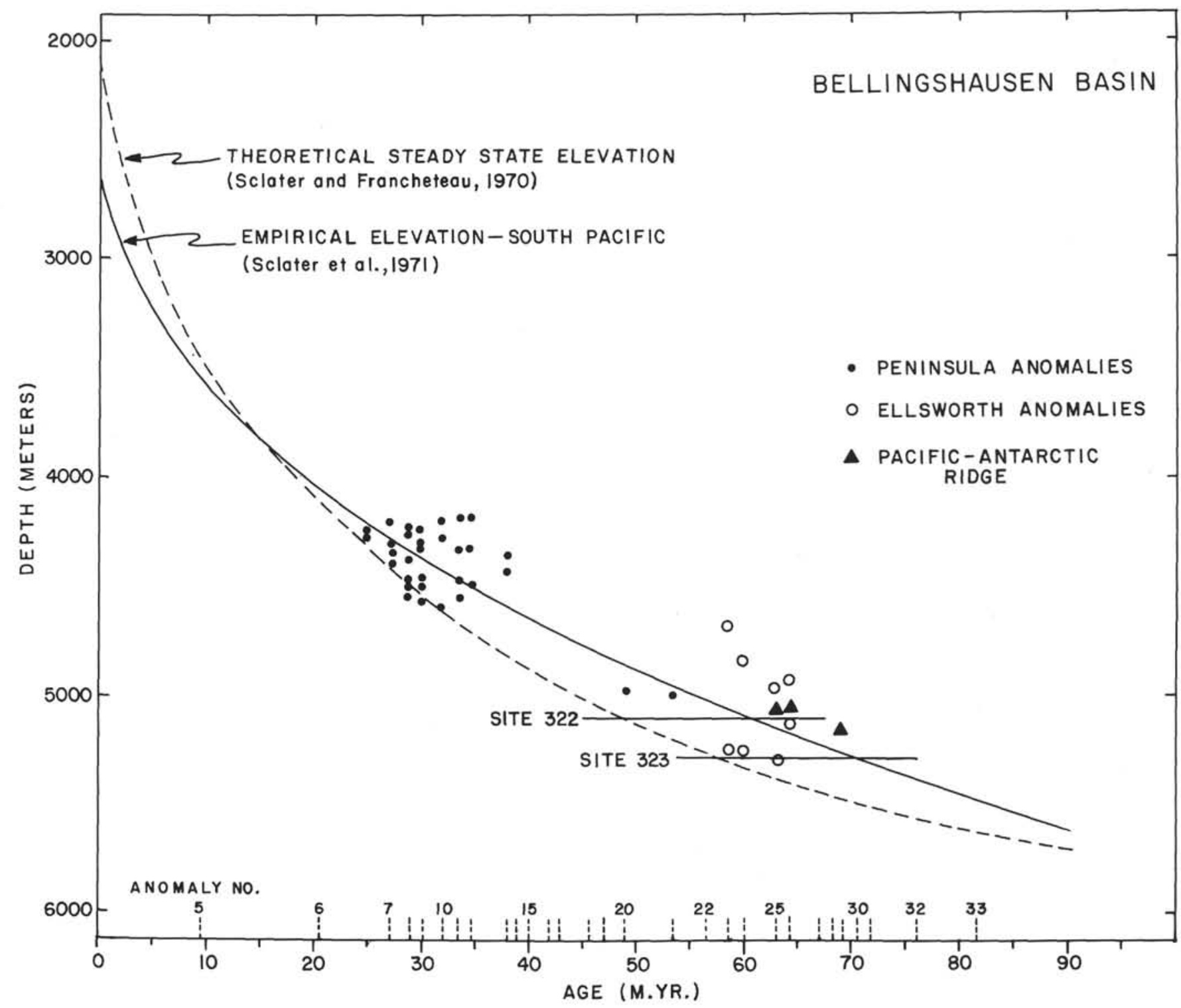

Figure 10. Plot of average depth versus age of crust in the Bellingshausen Basin (corrected for sediment overburden). Magnetic time scale is from Heirtzler et al. (1968).

beneath Marie Byrd Land during the Eocene to Miocene. This spreading center would have caused slight extension in the area and could acount for the Cenozoic alkaline volcanics in the area. A pole of rotation for the East and West Antarctic plates nearby in the Ross Sea would simultaneously require some compression in the vicinity of McMurdo Sound and Mount Erebus. We emphasize, however that we do not consider the Marie Byrd Land spreading center to represent postPaleocene activity of the Aluk Ridge southwest of the Tula Fracture Zone.

The magnetic lineations west of the Antarctic Peninsula and adjacent to the Pacific coast of Patagonia suggest that by about $50 \mathrm{~m} . \mathrm{y}$. ago a triple junction was active in the Pacific Basin in the region of rugged sea floor between $57^{\circ}$ and $60^{\circ} \mathrm{S}$. The orientation of the spreading centers and tectonic lineaments in the Pacific Basin and in the Drake Passage also suggests that spreading about these axes was responsible for the open- ing of the Drake Passage and the final dispersal of fragments of Andean crust about the Scotia Sea. The timing and mechanism of this dispersal are difficult to estimate from the sea-floor magnetic data; however, the presence of anomaly 6-age ocean crust in the Drake Passage suggests that a deep-water passage was formed there no later than the early Miocene.

As we discussed earlier, the basement age determined by drilling at Site 322 (10-25 m.y.) is in strong disagreement with sea-floor age inferred from both magnetic patterns and age-depth relationships. Basalt petrology and the drilling record indicate that interbedded sediment layers and extrusive igneous flows may have been penetrated at Site 322 (see Vennum, this volume), so that an unknown amount of sediment could lie below the basalt cored. This information and the age descrepancies suggest that the basalt cored at Site 322 represents early Miocene intra-plate volcanism. The volcanism would have occurred about the same time 


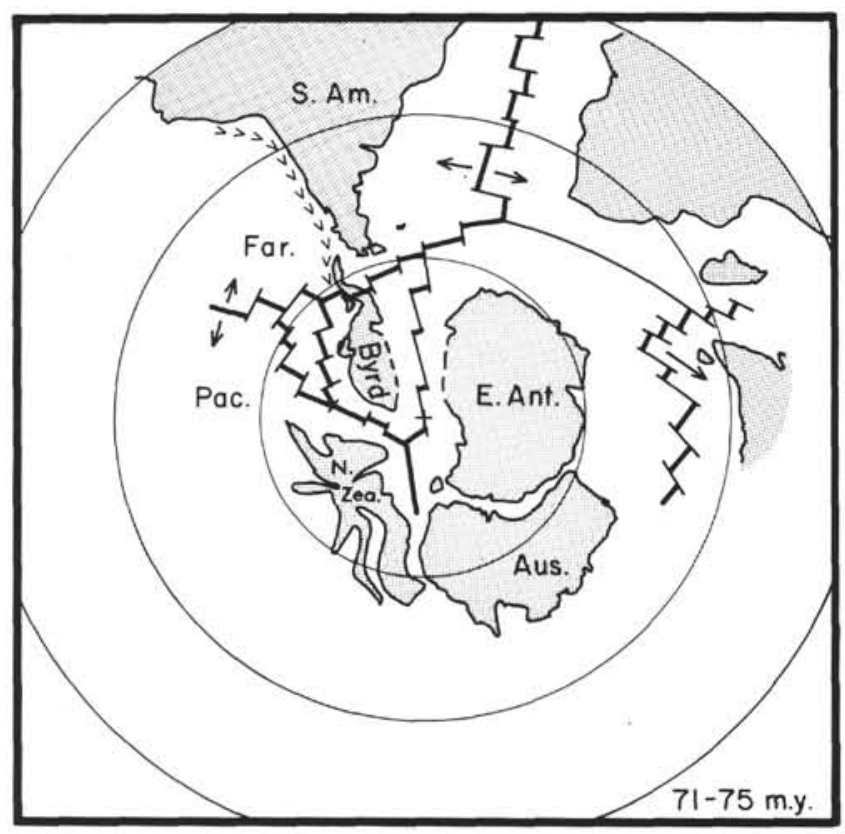

Figure 11a. A sketch based on McKenzie and Sclater (1971) and Molnar et al. (1975) to illustrate a possible configuration of crustal plates during the Late Cretaceous.

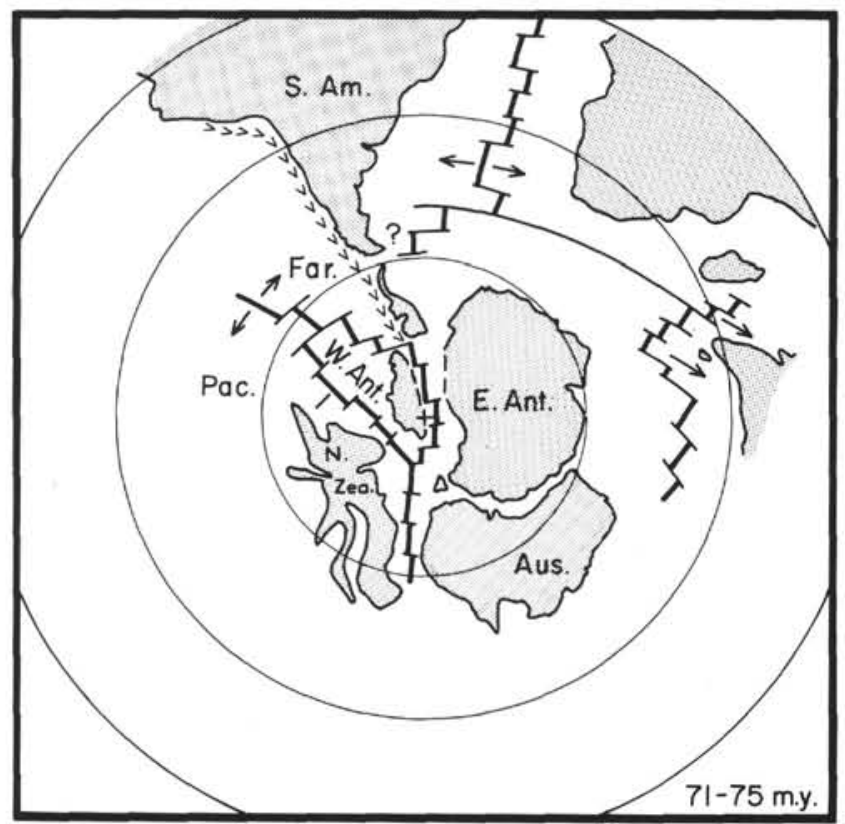

Figure 11b. An alternative sketch for the Late Cretaceous.

that the peninsula segment of the Aluk Ridge was subducted southeast of the site. Thus it is possible that slight plate adjustments and reorientation coincident with this event may have caused volcanism along the major tectonic lineaments near Site 322 .

Petrologic evidence indicates that one or more basalt sills were cored at Site 323 (Vennum, this volume). Potassium-argon dates on the basalt (46-47 m.y.) agree neither with paleontologic ages of overlying sediment (Maestrichtian) nor with age data from magnetic anomalies and age-depth relationships. However, the
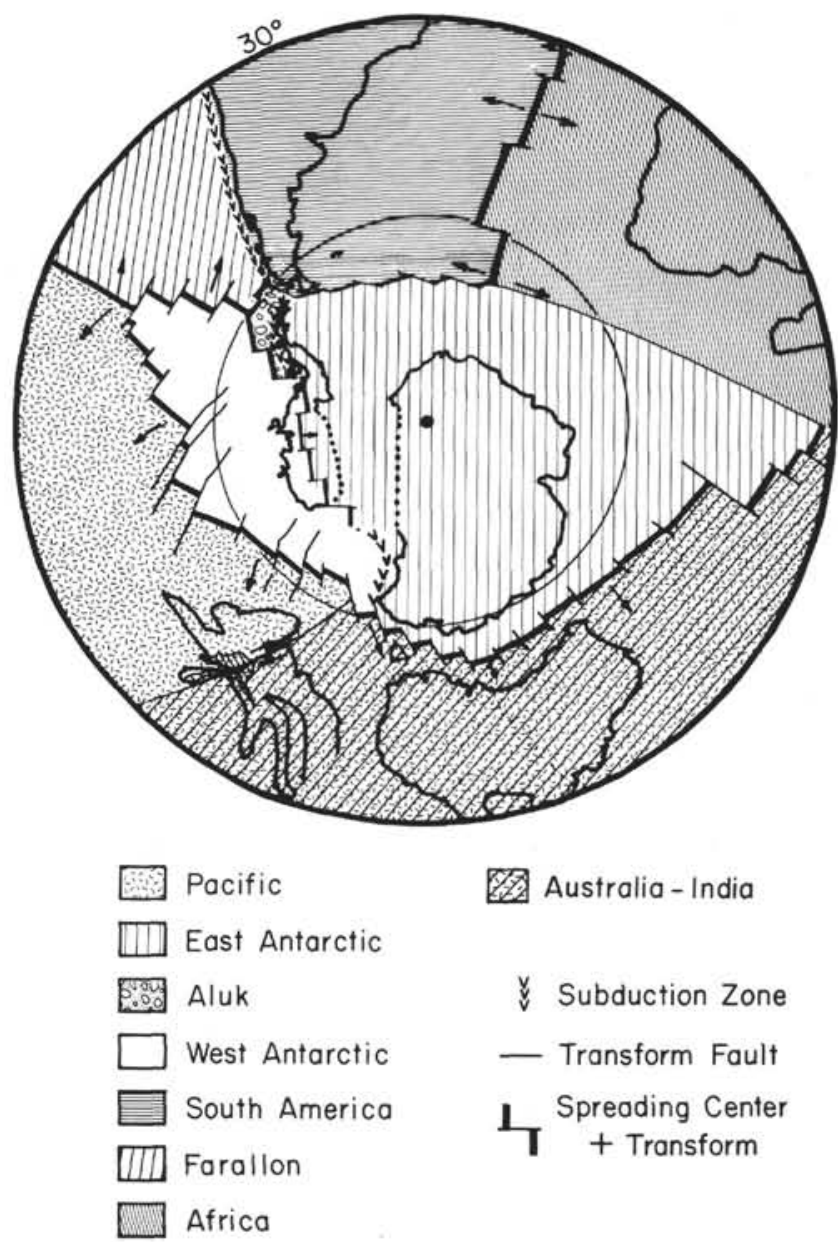

Figure 12a. Possible plate configurations in the Eocene to Miocene. See Figure $12 b$ for plate names.

presence of Maestrichtian sediment overlying the sill suggests that the true age of crust beneath the sill closely approaches the $70 \mathrm{~m} . \mathrm{y}$. age predicted by magnetics and crustal depth.

\section{CHARACTER OF ACOUSTIC BASEMENT}

The character of acoustic basement in the Bellingshausen Basin is quite variable and provides an additional useful parameter in interpreting Cenozoic crustal evolution in the area. Acoustic basement can be categorized into four morphological types varying essentially in degree of roughness (Figures 3 and 13).

The first is a very smooth, level horizon which returns a coherent echo. It is observed in the vicinity of Site 325 landward of the Palmer Ridge, and in the area of deep basement $(>7 \mathrm{sec})$ in the central basin to the west.

The second type is moderately smooth acoustic basement, occasionally with small-scale irregularities. It surrounds the smooth basement landward of the Palmer Ridge and locally occurs in patches beneath the continental rise to the west.

The third type exhibits moderate irregularity with an amplitude generally less than 200 meters, thus forming a fairly even, coherent reflector. This type of acoustic basement locally surrounds the smooth basement types 


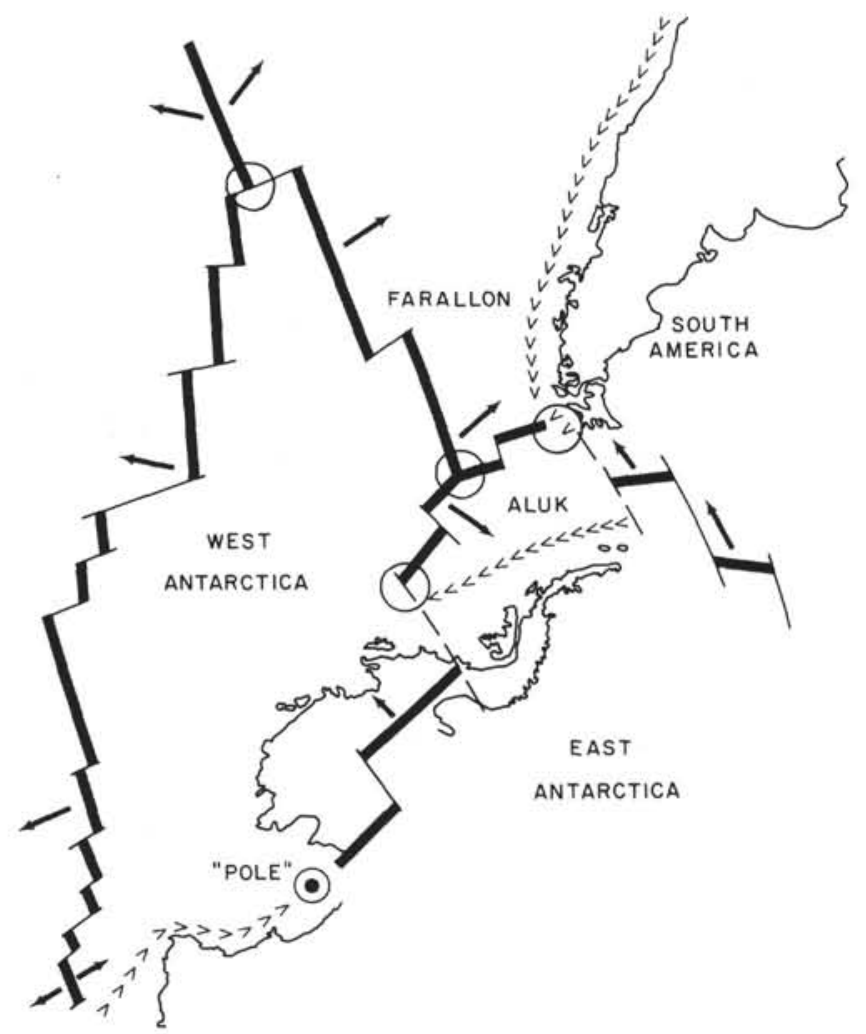

Figure 12b. A blowup of a portion of Figure $12 a$ to illustrate a possible configuration of the boundaries of the Aluk Plate northwest of the Antarctic Peninsula. The modern configurations of Patagonia and the Antarctic Peninsula are shown.

described above and appears to occur throughout much of the western basin.

The final morphologic variation is the more typical oceanic crust exhibiting sharp peaks and troughs with amplitudes up to several hundred meters. The most marked crustal irregularity is observed in the Palmer Ridge and north of Site 322 (Figure 5), although irregular acoustic basement with smaller amplitudes is common throughout the rest of the basin.

Compressional wave velocities of acoustic basement, determined from sonobuoy solutions, vary from about 3.5 to $6.1 \mathrm{~km} / \mathrm{sec}$, with principal modes at 4.2 to 4.6 $\mathrm{km} / \mathrm{sec}$ and 5.4 to $5.8 \mathrm{~km} / \mathrm{sec}$. The 4.2 to $4.6 \mathrm{~km} / \mathrm{sec}$ layer is thick enough to be resolved only in the areas of smooth to moderately smooth acoustic basement. However, a layer of similar velocity also can be inferred in the regions of moderately rugged basement, because higher velocity refractions ( 5.4 to $5.8 \mathrm{~km} / \mathrm{sec}$ ) originate from an interface 200 to 300 meters below acoustic basement.

There are two likely explanations for the 4.2 to 4.6 $\mathrm{km} / \mathrm{sec}$ layer. It may correlate with Layer $2 \mathrm{~A}$, which is widely documented in the Pacific in regions of relatively smooth acoustic basement and is thought to consist of chert or volcanics (Houtz et al., 1970). In the North Atlantic, recent drilling on Leg 37 of the Deep Sea Drilling Project suggests that Layer $2 \mathrm{~A}$ consists of interbedded basalt and metasediments (Scientific Staff,
1974). Secondly, the fact that the layer is best developed in regions of smooth acoustic basement suggests that ponded, high-velocity sediments may help form the interval, masking the underlying true basaltic basement (see Christensen et al., 1973). Smooth acoustic basement occurs in two regions where sediment would be likely to pond and subsequently acquire high velocities: (1) in the area of old, deep crust in the central basin, and (2) landward of the Palmer Ridge. In the latter area, drilling at Site 325 recovered calcite-cemented siltstones, sandstones, and conglomerates having velocities as high as $5.37 \mathrm{~km} / \mathrm{sec}$ from depths several hundred meters above acoustic basement (Tucholke and Edgar, this volume). Similar, extensive lithification at depth could create the smooth acoustic basement interface observed.

We prefer an explanation of the morphology and velocity of acoustic basement which combines these two interpretations. Thus areas of moderately irregular basement may include Layer $2 \mathrm{~A}$ and consist of interbedded basalts and metasediments. Drilling at Site 323, which indicates that one or more basalt sills were penetrated at the level of acoustic basement, lends support to this interpretation. Small ponds of high-velocity sediment also may have helped to level the areas between acoustic basement peaks.

The smooth acoustic basement is interpreted as ponded sediments; Layer $2 \mathrm{~A}$ may underlie it, but the two layers are not differentiated in sonobuoy solutions. The gradation in acoustic basement morphology therefore may reflect the relative influence of sediment ponding in evening out the basement topography.

One further correlation can be noted. West of the Tula Fracture Zone where the long-wavelength Ellsworth anomalies indicate crust was generated at spreading half-rates of $6 \mathrm{~cm} / \mathrm{yr}$, acoustic basement is generally smoother than in the area of the peninsula anomalies. Thus the degree of irregularity may be inversely related to rate of crustal accretion, as noted in other areas of the Pacific (Menard and Mammerickx, 1967).

\section{SUMMARY}

Magnetic, bathymetric, and seismic profiler data indicate that ocean crust in the southeast Pacific has been formed at three spreading centers: the Pacific-Antarctic Ridge, the Chile Ridge, and the Aluk Ridge. Northeasttrending anomalies that decrease in age towards West Antarctica indicate that oceanic crust in the Bellingshausen Basin was generated at the Aluk Ridge beginning in the Late Cretaceous. Since the Paleocene, the tectonic history of the Bellingshausen Basin has also been characterized by a progressive northeastward consumption of the spreading center along the Pacific margin of West Antarctica, with concurrent cessation of subduction. Thick continental-rise sediments now cover the former subduction zone, and we see little modern evidence in free-air gravity or deep seismic structure for the marginal trench. Spreading about the axes of the Aluk and Chile ridges may have been partly responsible for the initiation of a northeasterly trending spreading center and the opening of the Drake Passage by the end of the Paleogene. 

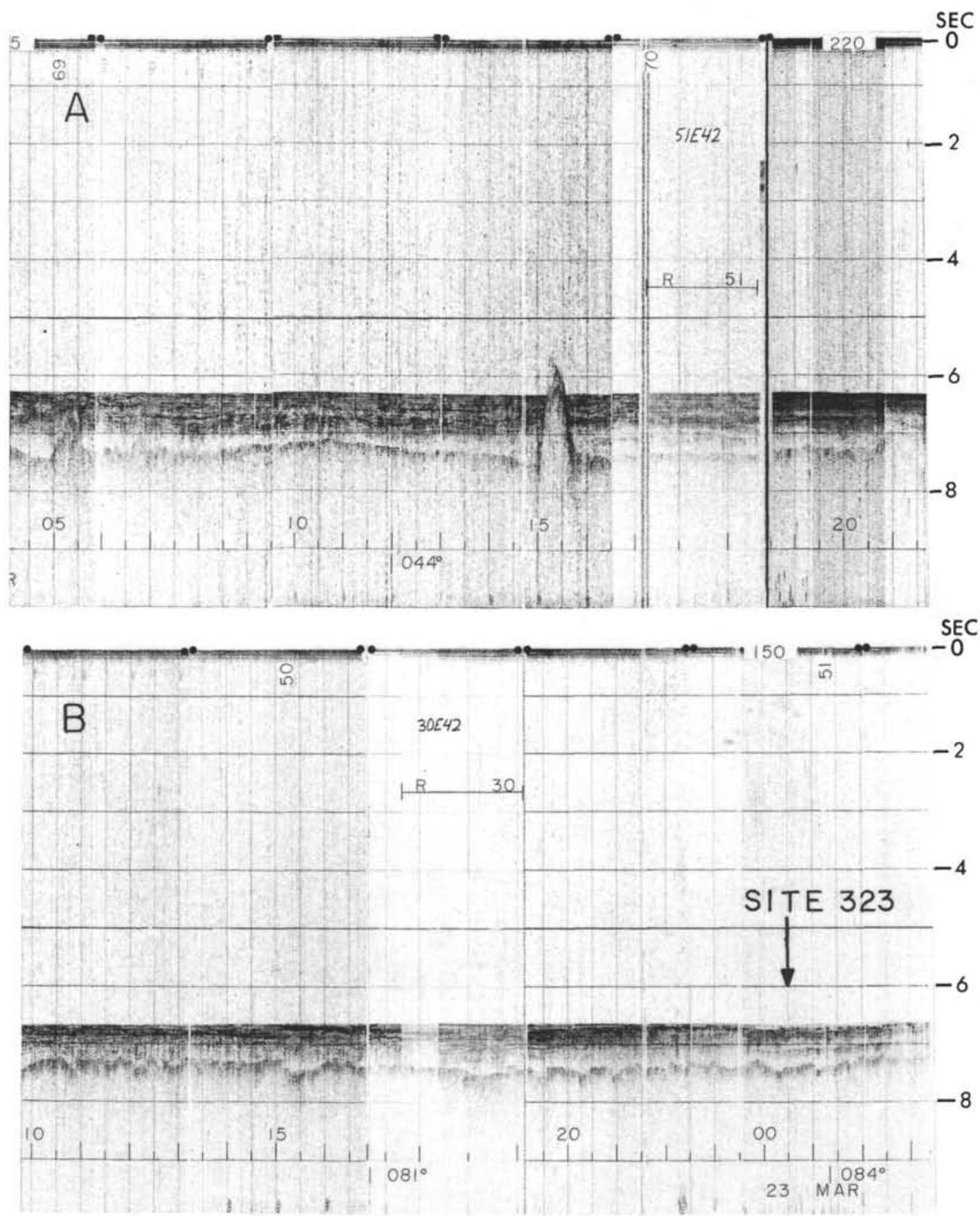

Figure 13. Seismic profiles showing variations in acoustic basement morphology: (a) smooth basement east of Site 323, (b) moderately irregular basement near Site 323.

The basement age determined by drilling at Site 323 agrees with late Cretaceous crustal formation at the Aluk Ridge, or possibly at the Pacific-Antarctic Ridge. However, the apparent basement age at Site 322 is much younger than that predicted by the magnetic patterns and may indicate early Miocene intra-plate volcanism.

The late Mesozoic and early Cenozoic plate history of the southeast Pacific and Antarctica are far from uniquely determined, but plausible models suggest that East and West Antarctica have acted as separate plates during the Cretaceous and Paleogene, with West Antarctica possibly fragmented at times into subplates.
Unusually long-wavelength anomalies north of Ellsworth Land indicate very rapid Paleocene spreading in at least one section of the Bellingshausen Basin, but we cannot yet relate this directly to West Antarctic history.

Basement structure and depth in the Bellingshausen Basin confirm and augment tectonic patterns suggested by magnetic data. Unusually smooth acoustic basement in two areas appears to result from ponding of highvelocity sediment which masks the underlying basalt in normal incidence and sonobuoy profiles. Sonobuoydetermined velocities intermediate between highvelocity sediment and basalt $(4.2$ to $4.6 \mathrm{~km} / \mathrm{sec})$ suggest 
the presence of Layer $2 \mathrm{~A}$ in the basin, possibly consisting of interlayered metasediments and basalt, which are locally thickened by the aforementioned sediment ponding. Acoustic basement in Paleocene crust in the basin is generally smoother than younger crust, and it may owe its relative smoothness to rapid crustal generation as indicated by the Ellsworth anomalies.

\section{ACKNOWLEDGMENTS}

Eltanin, Conrad, and Vema geophysical data collection and processing were supported by the National Science Foundation, Office of Polar Programs; and by NSF Grant GA 27281 and Office of Naval Research Contract N00014-67-A-01080004 . Sonobuoys were also furnished by the Office of Naval Research. We thank R. Houtz for the use of unpublished sonobuoy data and R. Larson, A. Watts, and J. Weissel for comments on the manuscript. During preparation of this paper, the authors were supported by NSF Grant GA 27281 (Ellen Herron and Brian Tucholke), and by ONR Contract N00014-67-A-0108-004 (Ellen Herron) and a Lamont-Doherty Postdoctoral Fellowship (Brian Tucholke).

\section{REFERENCES}

Baker, P.E., Davies, T.G., and Roobol, M.J., 1969. Volcanic activity at Deception Island in 1967 and 1969: Nature, v. 224 , p. $553-560$.

Barazangi, M. and Dorman, J., 1969. World seismicity maps compiled from ESSA Coast and Geodetic Survey epicenter data: Seism. Soc. Am. Bull., v. 59, p. 369-380.

Barker, P.F., 1971. Magnetic lineations in the Scotia Sea. In Adie, R.J. (Ed.), Antarctic geology and geophysics: Oslo (Universitets-forlaget), p. 17-26.

Christensen, N.I., Fountain, D.M., and Stewart, R.J., 1973. Oceanic crustal basement: A comparison of seismic properties of D.S.D.P. basalts and consolidated sediments: Marine Geol., v. 15, p. 215-226.

Dalziel, I.W.D. and Elliot, D.H., 1971. Evolution of the Scotia Arc: Nature, v. 233 , p. $246-252$.

Ewing, J.I., Ludwig, W.J., Ewing, M., and Eittreim, S.L., 1971. Structure of the Scotia Sea and Falkland Plateau: J. Geophys. Res., v. 76, p. 7118-7137.

Ewing, M., Ewing, J.I., Houtz, R.E., and Leyden, R., 1968. Sediment distribution in the Bellingshausen Basin. In Symp. Antarctic Oceanogr., Sept. 13-16, 1966, Santiago, Chile: Cambridge (Scott Polar Res. Inst.), p. 89-99.

Ewing, M., Houtz, R., and Ewing, J., 1969. South Pacific sediment distribution: J. Geophys. Res., v. 74, p. 2477-2493.

Grow, J.A. and Atwater, T., 1970. Mid-Tertiary tectonic transition in the Aleutian Arc: Geol. Soc. Am. Bull., v. 81, p. 3715-3722.

Hayes, D.E. and Ewing, M., 1971. The Louisville Ridge-a possible extension of the Eltanin Fracture Zone. In Reid, J.L. (Ed.), Antarctic oceanology I, Antarctic Res. Serv., v. 15: Washington (Am. Geophys. Union), p. 223-228.

Hayes, D.E. and Ringis, J., 1973. Sea floor spreading in a marginal basin: The Tasman Sea: Nature, v. 243, p. 86-88.

Heirtzler, J.R., Dickson, G.O., Herron, E.M., Pitman, W.C., III, and Le Pichon, X., 1968. Marine magnetic anomalies, geomagnetic field reversals, and motions of the ocean floor and continents: J. Geophys. Res., v. 73, p. 2119-2136.

Herron, E.M., 1971. Crustal plates and sea-floor spreading in the southeastern Pacific. In Reid, J.L. (Ed.), Antarctic oceanology I, Antarctic Res. Ser., v. 15: Washington (Am. Geophys. Union), p. 229-237.

1972. Sea-floor spreading and the Cenozoic history of the east-central Pacific: Geol. Soc. Am. Bull., v. 83, p. 1671-1692.

Herron, E.M. and Hayes, D.E., 1969. A geophysical study of the Chile Ridge: Earth Planet. Sci. Lett., v. 6, p. 77-83.

Houtz, R.E., 1974. Continental margin of Antarctica: PacificIndian sectors. In Burk, C.A. and Drake, C.L. (Eds.), The Geology of Continental Margins: New York (SpringerVerlag), p. 655-658.

Houtz, R.E., Ewing, J., and Buhl, P., 1970. Seismic data from sonobuoy stations in the northern and equatorial Pacific: J. Geophys. Res., v. 75, p. 5093-5111.

Houtz, R.E., Ewing, M., Hayes, D.E., and Naini, B.R., 1973. Sediment isopachs in the Indian and Pacific Ocean sectors $\left(105^{\circ} \mathrm{E}\right.$ to $\left.70^{\circ} \mathrm{W}\right)$ : Antarctic Map Folio Ser., Folio 17: Washington (Am. Geogr. Soc), p. 9-12.

Larson, R.L. and Chase, C.G., 1972. Late Mesozoic evolution of the western Pacific Ocean: Geol. Soc. Am. Bull., v. 83, p. $3627-3644$.

Mammerickx, J., Smith, S.M., Taylor, I.L., and Chase, T.E., 1974a. Bathymetry of the South Pacific: Scripps Inst. Oceanogr. IMR Tech. Rept. 53A, Chart No. 20, 1st ed., March 1974.

1974b. Bathymetry of the South Pacific: Scripps Inst. of Oceanography IMR Tech. Rept. 54A, Chart No. 21B, 1st ed., April 1974.

McKenzie, D. and Sclater, J.G., 1971. The evolution of the Indian Ocean since the Late Cretaceous: Geophys. J. Roy. Astron. Soc., v. 25, p. 437-528.

Menard, H.W. and Mammerickx, J., 1967. Abyssal hills, magnetic anomalies and the East Pacific Rise: Earth Planet. Sci. Lett., v. 2, p. 465-472.

Molnar, P., Atwater, T., Mammerickx, J., Smith, S.M., 1975. Magnetic anomalies, bathymetry and the tectonic evolution of the South Pacific since the Late Cretaceous: Geophys. J. Roy. Astron. Soc., v. 40 , p. $383-420$.

Pitman, W.C., III, Herron, E.M., and Heirtzler, J.R., 1968. Magnetic anomalies in the Pacific and sea-floor spreading: J. Geophys. Res., v. 73, p. 2069-2085.

Scientific Staff, 1974. Deep Sea Drilling Project Leg 37-the volcanic layer: Geotimes, v. 19, p. 16-18.

Sclater, J.G. and Francheteau, J., 1970. The implications of terrestrial heat flow observations on current tectonic and geochemical models of the crust and upper mantle of the earth: Geophys. J. Roy. Astron. v. 20, p. 509-542.

Sclater, J.G., Anderson, R.N., and Bell, M.L., 1971. Elevation of ridges and evolution of the central eastern Pacific: J. Geophys. Res., v. 76, p. 7888-7915.

Stump, E., 1973. Earth evolution in the Transantarctic Mountains and West Antarctica. In Tarling, D.H. and Runcorn, S.K. (Eds.), Implications of continental drift to the earth sciences: New York (Academic Press), v. 1, p. 909-924.

U.S. Naval Oceanographic Office Geomagnetic Surveys, 1970. Informal Rept. No. 70-18, U.S. Naval Oceanographic Office, Washington.

Vogt, P.R., Anderson, C.N., and Bracey, D.R., 1971. Mesozoic magnetic anomalies, sea-floor spreading and geomagnetic reversals in the southwestern North Atlantic: J. Geophys. Res., v. 76, p. 4796-4823.

Watts, A.B. and Talwani, M., 1974. Gravity anomalies seaward of deep-sea trenches and their tectonic implications: Geophys. J. Roy. Astron. Soc., v. 36, p. 57-90. 